\title{
GAMBARAN TINGKAT KEPUASAN PASIEN TERHADAP KUALITAS PELAYANAN KESEHATAN DI POLIKLINIK GIGI DAN MULUT RUMAH SAKIT UMUM PURI RAHARJA
}

\author{
I Gede Yogi Darma Raharja*, Sari Kusumadewi ${ }^{* *}$, Dewi Puri Astiti ${ }^{* *}$
}

Keywords:
Patient satisfaction,
Quality of health
service, SERVQUAL
dimension.

\section{ABSTRACT}

Background: Patient satisfaction on health service quality are comparison between patient perception before receiving service and after service received. High patient satisfaction will be achieved if the patient's expectation before receiving the service is fulfilled. Patient's expectations will be fulfilled if the services provided exceed quality, therefore, patient satisfaction is key marker of the quality health service. This aims of this study was to determine the description level of patient satisfaction to health services quality on Dental Polyclinic at Puri Raharja General Hospital.

Method: This study was a quantitative descriptive study with cross-sectional research design. The sampling method used was consecutive sampling with total sample 66 respondents. The datas were collected using questionnaires that had been tested for validity and reliability to determine patient satisfaction level to health service quality in five SERVQUAL dimension: tangibles, reliability, responsiveness, assurance and empathy.

Result: The results showed 57 respondent $(86,4 \%)$ satisfied with the quality of health services provided. In each dimension, the majority of respondents were satisfied except in the tangibles dimension.

Conclusion: Majority of patients who visited Dental Polyclinic at Puri Raharja General Hospital satisfied with the service given, except in the tangibles dimension, where $48,5 \%$ patient were unsatisfied

\section{PENDAHULUAN}

Tuntutan masyarakat akan pelayanan dibidang kesehatan semakin meningkat setiap tahunnya. Untuk mengantisipasi hal tersebut maka penting untuk menjaga kualitas pelayanan yang diberikan. Kualitas pelayanan di bidang kesehatan merupakan suatu bentuk penilaian pasien terhadap tingkat pelayanan yang diharapkan dengan tingkat pelayanan yang didapatkan). ${ }^{1}$ Harapan akan pelayanan kesehatan yang cepat dan tepat, biaya pengobatan yang terjangkau serta tenaga kesehatan yang terampil, ramah, dan komunikatif merupakan sebagian dari banyaknya tuntutan pasien terhadap penyedia jasa pelayanan kesehatan. ${ }^{2}$ Harapan-harapan pasien ini hanya akan terpenuhi jika pelayanan yang diberikan memiliki kualitas yang luar biasa dan melebihi persepsi pasien sebelum menerima pelayanan. ${ }^{1}$ Menurut Parasuraman dkk, ada lima dimensi yang dapat digunakan untuk menilai kualitas dari sebuah pelayanan yaitu dimensi tangibles atau tampilan fisik, reliability atau kehandalan, responsiveness atau kecepatan, assurance atau jaminan dan emphaty atau empati. ${ }^{3}$

Harapan dan tuntutan akan dimensi kecepatan, jaminan dan empati berada pada posisi tertinggi dalam prioritas pasien terhadap kualitas dari sebuah jasa pelayanan kesehatan. Kemampuan berkomunikasi, yang merupakan bagian dari dimensi empati menjadi komponen terpenting dalam menentukan puas

*Program Pendidikan Dokter Gigi Fakultas Kedokteran Universitas Udayana **Staf Pengajar Fakultas Kedokteran Universitas Udayana

Korespondensi: yogiraharja16@gmail.com 
atau tidaknya seorang pasien terhadap jasa pelayanan yang diberikan. ${ }^{4}$ Namun faktanya, pasien sering tidak puas terhadap kualitas serta jumlah informasi yang didapat dari tenaga kesehatan. Hal ini terlihat dari data hasil penelitian yang menyatakan bahwa 35\% - 40\% pasien merasa tidak puas saat berkomunikasi dengan tenaga kesehatan, khususnya dengan tenaga medis dokter. Data hasil penelitian yang dilakukan oleh Vaidyanathan dkk. (2013) tentang kepuasan pasien terhadap pelayanan kesehatan gigi dan mulut yang dilaksanakan di India tahun 2015, memberikan hasil persentase kepuasan pasien terhadap dimensi komunikasi sebesar $68,2 \%$, lebih rendah dibandingkan dimensi kenyamanan $83,02 \%$ dan dimensi kualitas teknis yang mencapai $93,06 \% .^{5}$

Selain faktor personal yang dimiliki oleh tenaga kesehatan, persepsi pasien tentang biaya dari sebuah pelayanan kesehatan juga berpengaruh terhadap kepuasan yang dirasakan oleh pasien. Berdasarkan hasil penelitian yang dilakukan oleh Jalimun dkk. (2014) didapatkan hasil bahwa kepuasan pasien terhadap jasa pelayanan kesehatan secara keseluruhan yang melibatkan dokter gigi, perawat gigi, bagian administrasi serta fasilitas non medis dalam kategori rendah sebesar $59,7 \%$, dengan variabel persepsi pasien terhadap biaya menjadi yang paling dominan berpengaruh terhadap kepuasan pasien. ${ }^{6}$ Pengalaman berkunjung juga berhubungan dengan tingkat kepuasan yang dirasakan pasien. Semakin sering pasien berkunjung, maka pasien telah merasakan kepuasan yang mendorong pasien untuk datang kembali berobat ke penyedia pelayanan kesehatan tersebut.

Rumah Sakit Umum Puri Raharja merupakan rumah sakit swasta tipe C yang berlokasi di jalan W.R. Supratman no. 14 \& 15, Denpasar, Bali. Rumah Sakit Umum Puri
Raharja memiliki 75 orang tenaga medis yang terdiri dari 10 orang dokter umum, 63 orang dokter spesialis, dan 2 orang dokter gigi. Berdasarkan hasil survei yang telah dilakukan, rata-rata jumlah kunjungan pasien tiap bulan ke Poliklinik Gigi dan Mulut Rumah Sakit Umum Puri Raharja tahun ini mengalami penurunan jika dibandingkan dengan tahun sebelumnya. Tahun 2015, rata-rata jumlah kunjungan pasien setiap bulannya berjumlah 42 orang, sedangkan tahun 2016 hingga data ini diambil pada bulan April, rata-rata jumlah kunjungan pasien setiap bulan berkisar 31 orang. Permasalahan inilah yang mendasari perlunya dilakukan penelitian ini untuk melihat gambaran tingkat kepuasan pasien terhadap kualitas pelayanan kesehatan di Poliklinik Gigi dan Mulut Rumah Sakit Umum Puri Raharja.

\section{METODE PENELITIAN}

Penelitian ini merupakan jenis penelitian deskriptif observasional dengan desain cross sectional. Pemilihan sampel dilakukan dengan teknik consecutive sampling, dimana semua responden yang datang berurutan dan memenuhi kriteria sampel dimasukkan dalam penelitian hingga jumlah responden yang diperlukan terpenuhi, yaitu sebanyak 66 orang yang didapat dari perhitungan jumlah sampel minimal. ${ }^{7}$ Adapun kriteria sampel dalam penelitian ini adalah: pasien yang bersedia berpartisipasi dengan menantangani informed consent, pasien dengan keluhan pada gigi dan mulut yang telah menerima perawatan oleh dokter gigi dan pasien yang tidak mengalami gangguan mental.

Kuisioner yang digunakan dalam peneltian ini terdiri atas pertanyaan yang meliputi usia, jenis kelamin, pendidikan terakhir, pekerjaan, jumlah kunjungan, serta lima dimensi kualitas pelayanan yang diukur dengan skala 
pengukuran Likert, dan dikategorikan menjadi sangat tidak puas (skor 1), tidak puas (skor 2), puas (skor 3) dan sangat puas (skor 4).

Pengukuran dimensi tampilan fisik I tangible

Responden dinyatakan puas apabila total skor jawaban responden dari masing-masing item memperoleh nilai minimal atau diatas angka 15. Sebaliknya, jika total skor dari masing-masing item memperoleh nilai dibawah angka 15, maka responden dinyatakan tidak puas.

\section{Pengukuran dimensi kehandalan / reliability}

Responden dinyatakan puas apabila total skor jawaban responden dari masing-masing item memperoleh nilai minimal atau diatas angka 12. Sebaliknya, jika total skor dari masing-masing item memperoleh nilai dibawah angka 12, maka responden dinyatakan tidak puas.

\section{Pengukuran dimensi kecepatan I responsiveness}

Responden dapat dinyatakan puas apabila total skor jawaban responden dari masingmasing item memperoleh nilai minimal atau diatas angka 9. Sebaliknya, jika total skor dari masing-masing item memperoleh nilai dibawah angka 9, maka responden dinyatakan

tidak puas.

Pengukuran dimensi jaminan / assurance

Responden dinyatakan puas apabila total skor jawaban responden dari masing-masing item memperoleh nilai minimal atau diatas angka 27. Sebaliknya, jika total skor dari masing-masing item memperoleh nilai dibawah angka 27 , maka responden dinyatakan tidak puas.

\section{Pengukuran dimensi empati / emphaty}

Responden dapat dinyatakan puas apabila total skor jawaban responden dari masingmasing item memperoleh nilai minimal atau diatas angka 21. Sebaliknya, jika total skor dari masing-masing item memperoleh nilai dibawah angka 21, maka responden dinyatakan tidak puas.

Pengukuran tingkat kepuasan terhadap kualitas pelayanan kesehatan

Responden dapat dinyatakan puas apabila nilai total pada kelima dimensi minimal atau diatas 81. Sebaliknya, jika total skor pada kelima dimensi memperoleh nilai dibawah angka 81, maka responden dinyatakan tidak puas.

\section{HASIL PENELITIAN}

Tabel 2.

Distribusi frekuensi tingkat kepuasan terhadap kualitas pelayanan kesehatan

\begin{tabular}{lc}
\hline Tingkat Kepuasan & $\mathrm{n}(\%)$ \\
\hline Puas & $57(86,4)$ \\
Tidak Puas & $9(13,6)$ \\
\hline Total & $66(100)$ \\
\hline
\end{tabular}

Tabel 3.

Distribusi frekuensi tingkat kepuasan terhadap dimensi tampilan fisik / tangibles

\begin{tabular}{ll}
\hline Tingkat Kepuasan & $\mathrm{n}(\%)$ \\
\hline Puas & $34(51,5)$ \\
Tidak Puas & $32(48,5)$ \\
\hline Total & $66(100)$ \\
\hline
\end{tabular}


Tabel 1.

Karakteristik demografi responden

\begin{tabular}{ll}
\hline Karakteristik Responden & $\mathrm{n}(\%)$ \\
\hline Usia (tahun) & \\
$17-45$ & $43(65,2)$ \\
$>$ > 45 & $23(34,8)$ \\
Jenis Kelamin & \\
$\quad$ Laki - Laki & $29(43,9)$ \\
Perempuan & $37(56,1)$ \\
Pendidikan Terakhir & \\
SMP & $4(6,1)$ \\
SMA/SMK & $8(12,1)$ \\
D1/D2/D3/D4 & $23(34,8)$ \\
S1 & $31(47,0)$ \\
Pekerjaan & \\
Tidak Bekerja & $3(4,5)$ \\
Ibu Rumah Tangga & $10(15,2)$ \\
PNS/POLRI/TNI & $7(10,6)$ \\
Pegawai Swasta & $38(57,6)$ \\
Wiraswasta / Pedagang & $3(4,5)$ \\
Petani / Nelayan / Buruh & $2(3,0)$ \\
Pensiunan & $3(4,5)$ \\
Kunjungan & \\
Pertama & $43(65,2)$ \\
Kedua & $13(19,7)$ \\
Ketiga & $10(15,2)$ \\
\hline Total & $66(100)$ \\
\hline
\end{tabular}

Tabel 4.

Distribusi frekuensi tingkat kepuasan terhadap item dimensi tampilan fisik / tangibles

\begin{tabular}{|c|c|c|c|c|}
\hline \multirow{2}{*}{ Item Tampilan Fisik } & \multicolumn{2}{|c|}{ Puas } & \multicolumn{2}{|c|}{ Kurang Puas } \\
\hline & $\mathrm{n}$ & $\%$ & $\mathrm{n}$ & $\%$ \\
\hline $\begin{array}{l}\text { Dokter gigi berpakaian } \\
\text { bersih dan rapi }\end{array}$ & 66 & 100 & - & - \\
\hline $\begin{array}{l}\text { Perawat gigi berpakaian } \\
\text { bersih dan rapi }\end{array}$ & 66 & 100 & - & - \\
\hline $\begin{array}{l}\text { Kondisi ruang tunggu } \\
\text { poliklinik bersih dan } \\
\text { nyaman }\end{array}$ & 57 & 86,3 & 9 & 13,7 \\
\hline $\begin{array}{l}\text { Tersedia media hiburan di } \\
\text { ruang tunggu poliklinik } \\
\text { seperti; TV, Koran, majalah, } \\
\text { dll }\end{array}$ & 24 & 36,3 & 42 & 63,7 \\
\hline $\begin{array}{l}\text { Lokasi parkir yang luas dan } \\
\text { mudah menjangkau lokasi } \\
\text { poliklinik }\end{array}$ & 18 & 27,2 & 48 & 72,8 \\
\hline
\end{tabular}


Tabel 5.

Distribusi frekuensi tingkat kepuasan terhadap dimensi kehandalan / reliability

\begin{tabular}{lc}
\hline Tingkat Kepuasan & $\mathrm{n}(\%)$ \\
\hline Puas & $65(98,5)$ \\
Tidak Puas & $1(1,5)$ \\
\hline Total & $66(100)$ \\
\hline
\end{tabular}

Tabel 6.

Distribusi frekuensi tingkat kepuasan terhadap item dimensi kehandalan / reliability

\begin{tabular}{lcccc}
\hline \multirow{2}{*}{ Item Kehandalan } & \multicolumn{2}{c}{ Puas } & \multicolumn{2}{c}{ Kurang Puas } \\
\cline { 2 - 5 } & $\mathrm{n}$ & $\%$ & $\mathrm{n}$ & - \\
\hline $\begin{array}{l}\text { Poliklinik buka tepat waktu } \\
\text { sesuai dengan jadwal yang } \\
\text { dijanjikan }\end{array}$ & 66 & 100 & & - \\
$\begin{array}{l}\text { Dokter gigi menjelaskan } \\
\text { setiap prosedur tindakan }\end{array}$ & 66 & 100 & - & - \\
$\begin{array}{l}\text { yang akan dilakukan } \\
\begin{array}{l}\text { Dokter gigi melakukan } \\
\text { pemeriksaan dengan teliti }\end{array}\end{array}$ & 66 & 100 & - & - \\
$\begin{array}{l}\text { Prosedur pelayanan } \\
\text { administrasi mudah dan }\end{array}$ & 65 & 98,4 & 1 & 1,6 \\
tidak berbelit-belit & & & & \\
\hline
\end{tabular}

Tabel 7.

Distribusi frekuensi tingkat kepuasan terhadap dimensi kecepatan / responsiveness

\begin{tabular}{lc}
\hline Tingkat Kepuasan & $\mathrm{n}(\%)$ \\
\hline Puas & $64(97,0)$ \\
Tidak Puas & $2(3,0)$ \\
\hline Total & $66(100)$ \\
\hline
\end{tabular}

Tabel 9.

Distribusi frekuensi tingkat kepuasan terhadap dimensi jaminan / assurance

\begin{tabular}{lc}
\hline Tingkat Kepuasan & $\mathrm{n}(\%)$ \\
\hline Puas & $65(98,5)$ \\
Tidak Puas & $1(1,5)$ \\
\hline Total & $66(100)$ \\
\hline
\end{tabular}


Tabel 8.

Distribusi frekuensi tingkat kepuasan terhadap item dimensi kecepatan / responsiveness

\begin{tabular}{lcccc}
\hline \multirow{2}{*}{ Item Kecepatan } & \multicolumn{2}{c}{ Puas } & \multicolumn{2}{c}{ Kurang Puas } \\
\cline { 2 - 5 } & $\mathrm{n}$ & $\%$ & $\mathrm{n}$ & $\%$ \\
\hline $\begin{array}{l}\text { Kecepatan tindakan dokter } \\
\text { gigi dalam mengatasi } \\
\text { keluhan yang pasien }\end{array}$ & 66 & 100 & - & - \\
$\begin{array}{l}\text { rasakan } \\
\begin{array}{l}\text { Kesigapan perawat gigi } \\
\text { dalam membantu setiap } \\
\text { tindakan yang dilakukan }\end{array}\end{array}$ & 65 & 98,4 & 1 & 1,6 \\
$\begin{array}{l}\text { dokter gigi } \\
\text { Kecepatan petugas }\end{array}$ & 65 & 98,4 & 1 & 1,6 \\
$\begin{array}{l}\text { administrasi dalam } \\
\text { memberikan pelayanan }\end{array}$ & & & & \\
\hline
\end{tabular}

Tabel 11.

Distribusi frekuensi tingkat kepuasan terhadap dimensi empati / emphaty

\begin{tabular}{lc}
\hline Tingkat Kepuasan & $\mathrm{n}(\%)$ \\
\hline Puas & $64(97,0)$ \\
Tidak Puas & $2(3,0)$ \\
\hline Total & $66(100)$ \\
\hline
\end{tabular}

Tabel 12.

Distribusi frekuensi tingkat kepuasan terhadap item dimensi empati / emphaty

\begin{tabular}{lcccc}
\hline \multirow{2}{*}{ Item Empati } & \multicolumn{2}{c}{ Puas } & \multicolumn{2}{c}{ Kurang Puas } \\
\cline { 2 - 5 } & $\mathrm{n}$ & $\%$ & $\mathrm{n}$ & $\%$ \\
\hline $\begin{array}{l}\text { Dokter gigi } \\
\text { menginformasikan nomor } \\
\text { telepon yang dapat }\end{array}$ & 51 & 77,2 & 15 & 22,8 \\
$\begin{array}{l}\text { dihubungi } \\
\text { Kesediaan dokter gigi } \\
\text { mendengarkan keluhan }\end{array}$ & 66 & 100 & - & - \\
$\begin{array}{l}\text { yang pasien dan keluarga } \\
\text { sampaikan }\end{array}$ & & & & \\
$\begin{array}{l}\text { Dokter gigi nyaman dan } \\
\text { mudah diajak }\end{array}$ & 66 & 100 & - & - \\
$\begin{array}{l}\text { berkomunikasi } \\
\text { Informasi yang diberikan } \\
\text { dokter gigi jelas dan } \\
\text { mudah dimengerti }\end{array}$ & 66 & 100 & - & - \\
$\begin{array}{l}\text { Dokter gigi menawarkan } \\
\text { alternatif perawatan lain }\end{array}$ & 66 & 100 & - & - \\
$\begin{array}{l}\text { Dokter gigi memahami dan } \\
\text { peduli pada keluhan yang } \\
\text { pasien rasakan }\end{array}$ & 66 & 100 & - & - \\
\hline
\end{tabular}


Tabel 10.

Distribusi frekuensi tingkat kepuasan terhadap item dimensi jaminan / assurance

\begin{tabular}{|c|c|c|c|c|}
\hline \multirow{2}{*}{ Item Jaminan } & \multicolumn{2}{|c|}{ Puas } & \multicolumn{2}{|c|}{ Kurang Puas } \\
\hline & $\mathrm{n}$ & $\%$ & $\mathrm{n}$ & $\%$ \\
\hline $\begin{array}{l}\text { Dokter gigi menjamin } \\
\text { kerahasiaan penyakit } \\
\text { pasien }\end{array}$ & 66 & 100 & - & - \\
\hline $\begin{array}{l}\text { Dokter gigi bertanggung } \\
\text { jawab terhadap setiap } \\
\text { prosedur tindakan yang } \\
\text { dilakukan }\end{array}$ & 66 & 100 & - & - \\
\hline $\begin{array}{l}\text { Dokter gigi bersikap ramah } \\
\text { dan sopan }\end{array}$ & 66 & 100 & - & - \\
\hline $\begin{array}{l}\text { Dokter gigi meminta ijin } \\
\text { pasien untuk membuka } \\
\text { mulut saat akan melakukan } \\
\text { pemeriksaan }\end{array}$ & 66 & 100 & - & - \\
\hline $\begin{array}{l}\text { Perawat gigi bersikap } \\
\text { ramah dan sopan }\end{array}$ & 65 & 98,4 & 1 & 1,6 \\
\hline $\begin{array}{l}\text { Petugas administrasi } \\
\text { bersikap ramah dan sopan }\end{array}$ & 63 & 95,4 & 3 & 4,6 \\
\hline $\begin{array}{l}\text { Pasien merasa aman } \\
\text { selama prosedur tindakan } \\
\text { dilakukan }\end{array}$ & 66 & 100 & - & - \\
\hline $\begin{array}{l}\text { Dokter gigi menggunakan } \\
\text { masker serta sarung } \\
\text { tangan pelindung }\end{array}$ & 66 & 100 & - & - \\
\hline $\begin{array}{l}\text { Perawat gigi menggunakan } \\
\text { masker serta sarung } \\
\text { tangan pelindung }\end{array}$ & 65 & 98,4 & 1 & 1,6 \\
\hline
\end{tabular}

\section{DISKUSI}

Kepuasan merupakan kondisi saat keinginan, harapan dan kebutuhan seseorang dapat terpenuhi. Berdasarkan penelitian yang telah dilaksanakan, diketahui bahwa secara keseluruhan distribusi responden yang menyatakan puas terhadap kualitas pelayanan kesehatan di Poliklinik Gigi dan Mulut Rumah Sakit Umum Puri Raharja adalah sebesar $86,4 \%$, atau lebih dari setengah jumlah total responden sudah merasa puas terhadap pelayanan yang diberikan. Selain itu, kepuasan pasien terhadap kualitas pelayanan kesehatan di Poliklinik Gigi dan Mulut Rumah Sakit Umum Puri Raharja dapat dinilai berdasarkan metode SERVQUAL yang membagi kualitas pelayanan kesehatan menjadi lima aspek dimensi yaitu, dimensi tampilan fisik / tangibles, dimensi kehandalan / reliability, dimensi kecepatan / responsiveness, dimensi jaminan / assurance dan dimensi empati / emphaty. 
Distribusi kepuasan pasien terhadap kualitas pelayanan kesehatan ditinjau dari dimensi tampilan fisik / tangibles, data hasil penelitian di Poliklinik Gigi dan Mulut Rumah Sakit Umum Puri Raharja menunjukan persentase responden yang menyatakan puas terhadap pelayanan yang diberikan adalah sebesar $51,5 \%$ sedangkan $48,5 \%$ responden menyatakan kurang puas. Pada indikator penampilan, seluruh responden tergolong puas terhadap penampilan yang ditampilkan oleh dokter gigi serta perawat gigi. Responden merasa dokter gigi serta perawat gigi telah berpenampilan bersih dan juga rapi. Hal ini sejalan dengan penelitian yang dilakukan oleh Angraini (2015) yang dalam penelitiannya menyebutkan bahwa 42 responden $(64,6 \%)$ puas terhadap penampilan dokter gigi di Poliklinik Gigi dan Mulut Rumah Sakit Umum Daerah (RSUD) Tenriawaru, Kabupaten Bone. ${ }^{8}$ Disebutkan pula bahwa penampilan pelayanan tidak hanya sebatas pada tampilan fisik bangunan yang megah, tetapi juga penampilan petugas kesehatan dan ketersediaan sarana dan prasarana penunjang guna memberikan kepuasan terhadap pasien. Penelitian yang dilakukan oleh Sembel dkk. (2014) juga menemukan hasil indeks kepuasan responden terhadap penampilan dokter gigi sebesar $81,6 \%$ dalam kategori sangat puas. ${ }^{2}$

Pada indikator sarana dan prasarana, item yang membahas kondisi ruang tunggu poliklinik menunjukan hasil mayoritas responden $(86,3 \%)$ cenderung puas terhadap kondisi ruang tunggu poliklinik yang dirasa bersih dan nyaman. Sisanya $(13,7 \%)$ responden merasa kurang puas terhadap item ini karena merasa kondisi ruang tunggu poliklinik kurang nyaman dan juga sempit. Berdasarkan hasil observasi peneliti, hal ini cenderung disebabkan karena responden datang pada saat jam kunjungan poliklinik umum, yang berada tepat disebelah poliklinik gigi, sedang ramai sehingga menyebabkan responden harus berbagi ruang tunggu dengan pasien lainnya. Dengan kondisi ruang tunggu poliklinik yang tidak terlalu luas, maka pasien harus duduk berdesakan ataupun harus rela menunggu diluar dikarenakan kekurangan tempat duduk.

Selanjutnya, untuk item tersedianya media hiburan di ruang tunggu poliklinik dan lokasi parkir yang luas serta mudah menjangkau lokasi poliklinik, mayoritas responden menyatakan kurang puas dengan persentase masingmasing $63,7 \%$ dan $72,8 \%$. Ketidakpuasan ini disebabkan karena responden merasa tidak tersedianya media hiburan di ruang tunggu poliklinik saat responden sedang menunggu giliran pemeriksaan. Selain itu, responden juga kesulitan untuk mengakses poliklinik akibat lokasi poliklinik yang terpisah dari lokasi rumah sakit, kecilnya tanda penunjuk lokasi poliklinik, serta kondisi lokasi parkir yang sempit. Selain itu, kondisi tempat parkir poliklinik yang sempit dan berada tepat dipinggir jalan raya menyebabkan pasien kesulitan untuk memarkirkan kendaraan mereka. Tak jarang pasien harus memarkirkan kendaraan mereka jauh dari lokasi poliklinik atau di gedung utama rumah sakit yang berada diseberang jalan dan berjalan kaki menuju lokasi poliklinik.

Distribusi kepuasan pasien terhadap kualitas pelayanan kesehatan ditinjau dari dimensi kehandalan / reliability, hampir keseluruhan responden $(98,5 \%)$ menyatakan puas terhadap kualitas pelayanan yang diberikan. Pada indikator waktu, seluruh responden puas terhadap jam buka poliklinik yang tepat waktu dan sesuai dengan jadwal yang dijanjikan. Pada indikator prosedur pelayanan, responden merasa dokter gigi sudah memberikan penjelasan untuk setiap 
prosedur tindakan yang akan dilakukan serta melakukan pemeriksaan dengan teliti terhadap setiap keluhan yang dirasakan responden. Untuk item prosedur pelayanan administrasi, mayoritas responden (98,4\%) menyatakan prosedur pelayanan administrasi poliklinik mudah dan tidak terbelit-belit. Hasil penelitian ini sejalan dengan penelitian yang dilakukan oleh Sembel dkk. (2014) yang dalam penelitiannya menyebutkan bahwa indeks ratarata kepuasan pasien berdasarkan dimensi pelayanan kehandalan / reliability adalah sebesar $84,5 \%$ dengan kategori sangat puas. Anas dan Abdullah (2008) dalam penelitiannya juga menyebutkan 70 responden $(82,4 \%)$ menyatakan puas terhadap kehandalan / reliability yang ditunjukan petugas kesehatan di poli gigi RSUPWS Makassar. ${ }^{9}$ Dalam penelitian tersebut juga disebutkan kehandalan I reliability petugas kesehatan merupakan kemampuan petugas kesehatan baik dokter maupun perawat dalam melakukan tindakan guna memenuhi kebutuhan pasien.

Distribusi kepuasan pasien terhadap kualitas pelayanan kesehatan ditinjau dari dimensi kecepatan / responsiveness, mayoritas responden $(97,0 \%)$ menyatakan puas terhadap kualitas pelayanan yang diberikan. Dimensi ini hanya memiliki satu indikator kecepatan yang dibagi menjadi tiga item. Untuk item kecepatan tindakan dokter gigi, seluruh responden merasa dokter gigi sudah bekerja cepat dalam mengatasi keluhan yang responden rasakan. Untuk item kesigapan perawat gigi membantu tindakan dokter gigi dan kecepatan petugas administrasi memberikan pelayanan, $(98,4 \%)$ responden menyatakan puas. Hasil penelitian ini sejalan dengan penelitian yang dilakukan oleh Angraini (2015) yang menyatakan bahwa $43,1 \%$ pasien menyatakan puas terhadap kecepatan dokter gigi menangani keluhan pasien dan ketanggapan dokter gigi dalam menyelesaikan keluhan pasien serta $41,5 \%$ pasien puas pada kecepatan bagian administrasi dalam memberikan pelayanan di Rumah Sakit Umum Daerah (RSUD) Tenriawaru, KabupatenBone. ${ }^{8}$ Dalam penelitian tersebut juga disebutkan beberapa indikator dalam kecepatan / responsiveness antara lain tindakan cepat oleh dokter, perawat dan bagian administrasi dalam memberikan informasi yang jelas kepada pasien serta kemampuan dalam memberikan tanggapan yang cepat dalam menyelesaikan keluhan pasien. Sembel dkk. (2014) dalam penelitiannya juga mendapatkan hasil indeks rata-rata kepuasan pasien berdasarkan dimensi pelayanan daya tanggap / responsiveness adalah sebesar $84,1 \%$ dengan kategori sangat puas. ${ }^{2}$

Distribusi kepuasan pasien terhadap kualitas pelayanan kesehatan ditinjau dari dimensi jaminan / assurance, (98,5\%) responden menyatakan puas terhadap kualitas pelayanan yang diberikan. Hasil ini sejalan dengan penelitian yang dilakukan oleh Anas dan Abdullah (2008) yang mengatakan bahwa $76,5 \%$ responden merasa puas atas jaminan dan kepastian yang diberikan petugas kesehatan. Sembel dkk (2014) juga mendapatkan hasil indeks rata-rata 80,9\% responden dengan kategori sangat puas terhadap dimensi jaminan. ${ }^{2}$ Dimensi jaminan / assurance dalam penelitian ini dibagi menjadi empat indikator, antara lain : kompetensi, kredibilitas, kesopanan dan keamanan. Pada indikator kompetensi dan kredibilitas, seluruh responden menyatakan puas terhadap dokter gigi yang menjamin kerahasiaan data penyakit yang diderita pasien dan dokter gigi yang bertanggung jawab terhadap setiap prosedur tindakan yang dilakukan. Pada indikator kesopanan, responden menyatakan puas 
terhadap sikap dokter gigi yang ramah dan sopan dan meminta ijin pasien untuk membuka mulut saat akan melakukan pemeriksaan.

Pada item sikap perawat gigi, mayoritas responden menyatakan puas sedangkan item sikap petugas administrasi, mayoritas responden menyatakan puas namun ada tiga responden $(4,6 \%)$ yang menyatakan kurang puas. Responden merasa sikap petugas administrasi kurang ramah dan kurang sopan. Berdasarkan hasil observasi peneliti, ketidakpuasan ini disebabkan oleh karena situasi poliklinik yang sedang ramai menyebabkan petugas administrasi kurang maksimal dalam memberikan pelayanannya. Pada indikator keamanan, tidak ada responden yang menyatakan kurang puas terhadap pelayanan yang diberikan. Pasien merasakan keamanan yang terjamin saat dokter gigi melakukan tindakan serta dokter gigi dan perawat gigi menggunakan alat pelindung diri seperti masker dan sarung tangan saat melakukan tindakan perawatan sehingga pasien merasa puas.

Distribusi kepuasan pasien terhadap kualitas pelayanan kesehatan ditinjau dari dimensi empati / emphaty, $(97,0 \%)$ responden menyatakan puas terhadap kualitas pelayanan yang diberikan. Hasil penelitian ini sejalan dengan penelitian yang dilakukan oleh Sembel dkk (2014) yang dalam penelitiannya menyebutkan bahwa indeks rata-rata kepuasan pasien berdasarkan dimensi pelayanan empati / emphaty adalah sebesar $86,4 \% .^{2}$ Bata dkk. (2013) dalam penelitiannya juga menemukan hal yang sejalan dengan $95,7 \%$ responden menyatakan telah mendapat perhatian yang baik dari petugas kesehatan rumah sakit. ${ }^{1}$ Dimensi empati / emphaty dalam penelitian ini dibagi menjadi tiga indikator, yaitu akses, komunikasi dan kemampuan memahami.
Pada indikator akses, mayoritas responden $(77,2 \%)$ menyatakan puas terhadap informasi yang diberikan dokter gigi terkait nomor telepon yang dapat dihubungi bila terjadi keluhan kembali. Namun, $(22,8 \%)$ responden menyatakan kurang puas. Hasil observasi peneliti selama berada di poliklinik melihat ketidakpuasan ini cenderung disebabkan karena keluhan pasien yang tidak begitu parah sehingga setelah dilakukan tindakan perawatan pasien tidak memerlukan kunjungan kembali dan posisi poliklinik yang berada dibawah nama rumah sakit sehingga dokter gigi tidak menginformasikan kembali nomor telepon yang dapat dihubungi.

Pada indikator komunikasi dan kemampuan memahami, seluruh responden menyatakan puas terhadap pelayanan yang diberikan. Responden merasa dokter gigi bersedia mendengarkan keluhan yang disampaikan pasien dan keluarga, dokter gigi nyaman dan mudah untuk diajak berkomunikasi, informasi yang diberikan dokter gigi jelas dan mudah untuk dipahami, dokter gigi menawarkan alternatif perawatan lain jika pasien menolak perawatan yang ditawarkan dan dokter gigi mampu untuk memahami dan peduli terhadap keluhan yang dirasakan pasien. Hal ini sejalan dengan pendapat Bata dkk (2013) yang dalam penelitiannya menyatakan bahwa perhatian petugas kesehatan di rumah sakit mempunyai hubungan terhadap kepuasan yang dirasakan oleh pasien. ${ }^{1}$

\section{KESIMPULAN}

Berdasarkan uraian yang telah dijabarkan diatas, maka dapat disimpulkan bahwa mayoritas pasien kunjungan ke Poliklinik Gigi dan Mulut Rumah Sakit Umum Puri Raharja puas terhadap pelayanan yang diberikan, 
kecuali pada dimensi tampilan fisik menunjukan $48,5 \%$ responden menyatakan kurang puas.

\section{DAFTAR PUSTAKA}

1. Bata, Y. W., Arifin, H. Muh. A., Darmawansyah. Hubungan Kualitas Pelayanan Kesehatan Dengan Kepuasan Pasien Pengguna Askes Sosial Pada Pelayanan Rawat Inap di RSUD Lakipadada Kabupaten Tana Toraja Tahun 2013. 2013. hal. 1-12.

2. Sembel, M., Opod, H., Hutagalung, B.S.P., Gambaran Tingkat Kepuasan Pasien Terhadap Perawatan Gigi dan Mulut, Jurnal e-GiGi. 2014. 2(2).

3. Muninjaya, A, A, G.. Manajemen Mutu Pelayanan Kesehatan. 2rd ed. Jakarta: Penerbit Buku Kedokteran EGC. 2015. hal. 1-18.

4. Dewi, F. D., Sudjana, G., Oesman, Y. M., Patient Satisfaction Analysis on Service Quality of Dental Health Care Based on Empathy and Responsiveness, Dental Research Journal. 2011. 8(4):172-177.

5. Vaidyanathan S., Susmitha T. S., Rajkumar, M., Ganesh, A., Balaji, S. K., Kandaswamy, D., Patient Satisfaction With Dental Services at
A Rural Health Care Centre: A Questionnaire Survey. Journal Intra Oral Health 2015. 2013. 7(10):62-64.

6. Jalimun, Y. P., Widjanarko, B., Peitojo, H., Kepuasan Pasien di Balai Pengobatan Gigi (BPG) Puskesmas Kahuripan Kota Tasikmalaya. Jurnal Kesehatan Komunitas Indonesia. 2014. 10(1):898-910.

7. Sastroasmoro, S., Ismael, S., Dasar-Dasar Metodologi Penelitian Klinis. 5th ed. Jakarta: Sagung Seto. 2014. hal. 88-102.

8. Angraini, A. I., Kepuasan Pasien Terhadap Mutu Pelayanan Kesehatan Gigi di Poliklinik Gigi dan Mulut Rumah Sakit Umum Daerah (RSUD) Tenriawaru Kabupaten Bone. Skripsi. Fakultas Kedokteran Gigi Universitas Hasanuddin, Makassar. 2015.

9. Anas, A. St. A., Abdullah, A. Z., Studi Mutu Pelayanan Berdasarkan Kepuasan Pasien di Klinik Gigi dan Mulut RSUP Dr. Wahidin Sudirohusodo Makasar, Dentofasial. 2008. 7(2):99-106. 